\title{
Mobbing and its Effects on Turkish Nurses: A National Literature Review
}

\author{
Betül Sönmez $^{*}$, Aytolan Yildirim ${ }^{2}$ \\ ${ }^{1}$ Assistant Professor, PhD, BSN, Department of Nursing Management, Istanbul University-Cerrahpasa Florence \\ Nightingale Faculty of Nursing \\ ${ }^{2}$ Professor, PhD, BSN, Department of Nursing Management, Istanbul University-Cerrahpasa Florence \\ Nightingale Faculty of Nursing
}

\begin{tabular}{l} 
Keywords: \\
Mobbing, Psychological \\
Violence, Nurses, Turkey, \\
Literature Review \\
\hline Received \\
07 January 2018 \\
Received in revised form \\
01 July 2018 \\
Accepted \\
05 July 2018 \\
\hline
\end{tabular}

Correspondence:

betul.sonmez@istanbul.edu.tr

\begin{abstract}
This review aims to methodically analyze studies regarding mobbing behavior prevalence, individuals performing this behavior and the effects of mobbing on Turkish nurses. Five databases were searched thoroughly on November 2014 with no time limitation to identify the studies in English and Turkish that evaluated mobbing and its effects on nurses in Turkey. Of 71 records found by initial search, only 38 studies met the inclusion criteria. The findings were obtained using the results of 38 studies carried out in the past 13 years in Turkey. Analysis of the incidences of mobbing behavior revealed a broad spectrum, ranging from rarely experiences to $100 \%$ experiences. Victims mostly experienced mobbing from their managers, the most common consequence of these actions related to the psychological effects. The high frequency of exposure of nurses to mobbing behavior in such a large sample highlights the importance of considering this issue in terms of individual and institutional consequences that adversely affect the performance of nurses.
\end{abstract}

CAIMI Journals

Mobbing is a global multidimensional workplace problem which has increasingly drawn attention in the past years, and a similar trend is also observable in Turkey. The long-term antagonistic behavior experienced by individuals in their workplace have been expressed by notions such as psycho-terror, threatening, accusation, terrorizing and harassment. The Ministry of Labor and Social Security has defined mobbing in accordance with literature (Johnson, 2009; Yildirim \& Yildirim, 2007) in the Psychological Harassment (Mobbing) Information Guide (The Ministry of Labor and Social Security, 2014) as "any kind of 
antagonistic, intentional and negative attitude and behavior of one or more employee against others, systematically persisting for a specific period of time aimed to terrorize, passivate or lay off the victims, harming their health, personal values, professional statuses or social relations". According to this guide, mobbing can be comparable with negative behavior such as conflicts and rudeness in workplace, while physical violence, sexual harassment and/or insulting behavior are not considered mobbing due to the legal issues and their consequences. Similarly, negative attitude, behavior, argument or conflict which is not continuous and can be attributed to stress and workload is not evaluated as mobbing behavior. Any behavior outside the workplace is also excluded from this category (The Ministry of Labor and Social Security, 2014).

The presence of mobbing in workplace has been accepted in Turkey using the above description. The Prime Minister Circular (2011) has been published as a means of mobbing prevention, and Labor and Social Security Communication Center helpline, ALO170, provides professional help and support to victims.

\section{Theoretical Framework}

Studies regarding intimidation in the workplace have been conducted in many other countries in addition to Turkey, including Australia, England, the United States of America (USA), Iraq and Spain. The constant increase in the number of studies conducted in this area is clearly apparent (Johnson, 2009; Fornès, Cardoso, Castello, \& Gili, 2011).

It was reported that $44 \%$ of nurses in England (Quine, 2001), 50\% of nurses in Australia (Johnson, 2009), 31\% of nurses in the United States of America (Simon, 2008), and 18.9\% of nurses in Spain (Fornès et al. 2011) were exposed to mobbing, bullying or harassment behaviors and $91 \%$ of nurses in Iraq (AbuAlRub, Khalifa, \& Habbib, 2007) were exposed to workplace violence (including mobbing). According to literature, analysis of the profile of individuals expressing mobbing behavior reveals managers at the top of the list, followed by colleagues, physicians, other healthcare workers, patients and their relatives (Hutchinson, Wilkes, Jackson, \&Vickers, 2010; Yildirim \& Yildirim, 2007).

Since the early 2000s, studies on nurses were among the first studies performed on this topic, and there has been a striking increase in the number of studies performed since 2007 . According to the study by Efe and Ayaz (2010), the prevalence of mobbing in Turkish nurses is higher than the worldwide value and according to some studies, nurses experience the highest rate of mobbing among healthcare workers (Özen-Çöl, 2008; Şahin \& Dündar, 2011).

\section{Method}

\section{Aim and Type of Research}

This review aims to methodically analyze studies regarding (1) mobbing behavior prevalence, (2) individuals performing this behavior and (3) the effects of mobbing behavior on Turkish nurses.

Questions of the study were determined as follows: Nationally,

1. What is the rate of mobbing behavior incidents experienced by nurses at their workplace?

2. What are the most common mobbing behavior? 
3. What are the profiles of individuals performing these behavior?

4. What are the effects of mobbing behavior on nurses?

5. What are the reactions of nurses to mobbing behavior?

\section{Study Selection}

Studies are selected according to a search performed in November 2014, using the Turkish and English keywords "mobbing (OR) bullying, psychological terror/violence, emotional violence"; (AND) "nurses, (OR) healthcare workers"; (AND) "Turkey" in PubMed, Science Direct, Ebscohost, National Thesis Centre database and Google search engine by the first author. The studies reached upon literature review were evaluated by both researchers. They were included in the study with joint decision by considering inclusion/exclusion criteria.

\section{Inclusion/Exclusion Criteria}

The inclusion and exclusion criteria are identified in Table 1. The results of the study selection process are depicted in Figure 1. A total of 38 studies that met the inclusion criteria were used in this analysis.

Table 1

Inclusion and Exclusion Criteria

\begin{tabular}{|c|c|c|}
\hline & Inclusion criteria & Exclusion criteria \\
\hline Country & Studies performed in Turkey & \\
\hline Year & No limits on publication year & \\
\hline Study design & All study designs & \\
\hline Participants & $\begin{array}{l}\text { Studies performed on nurses or healthcare workers } \\
\text { including nurses }\end{array}$ & $\begin{array}{l}\text { Studies on healthcare workers which do not } \\
\text { explicitly include nurses } \\
\text { Studies performed on head nurses, nurse } \\
\text { academicians or nurse students }\end{array}$ \\
\hline Scope & $\begin{array}{l}\text { Studies with the topic "mobbing", including at least } \\
\text { one of the following information or results: mobbing } \\
\text { prevalence, profile of individuals exhibiting mobbing } \\
\text { behavior, effects of mobbing on nurses and escape } \\
\text { behavior of victims }\end{array}$ & $\begin{array}{l}\text { Studies without any of the information mentioned } \\
\text { in the criteria in summary or full text }\end{array}$ \\
\hline Language & Publications in English or Turkish & Systematic compilations or reports \\
\hline $\begin{array}{l}\text { Publication } \\
\text { type }\end{array}$ & $\begin{array}{l}\text { Published articles or unpublished master's or } \\
\text { doctorate theses } \\
\text { Access to summary or full text of article }\end{array}$ & $\begin{array}{l}\text { Repetitive studies (thesis studies also published } \\
\text { as articles) } \\
\text { Verbal or poster reports }\end{array}$ \\
\hline
\end{tabular}


Literature search in NCBI PubMed, Science Direct, Ebscohost, National Thesis

Centre database and Google Scholar:

$$
n=71 \text { studies }
$$

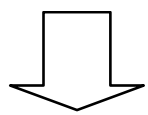

\section{Excluded ( $n=33$ studies $)$}

- Studies on healthcare workers do not explicitly include nurses $(n=10)$

- Studies do not have any of the information mentioned in the criteria in summary or full text $(n=4)$

- Studies include aggression $(n=7)$

- Systematic compilations or reports $(n=3)$

- Repetitive studies (thesis studies also publiced as articles) $(n=4)$

- Studies are performed on head nurses, academicians or students $(n=4)$

- Study was designed insufficent sample $(n=1)$

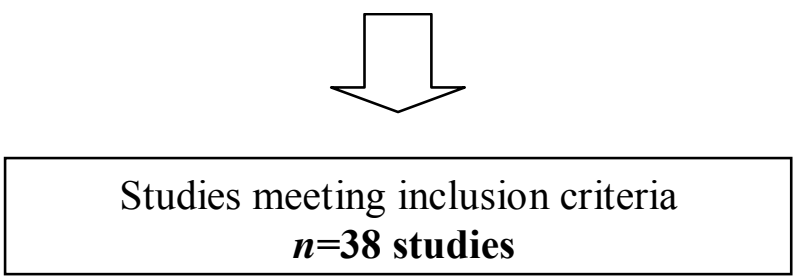

Figure 1. Selection process flowchart

\section{Study Quality}

The quality of the studies was evaluated in accordance with the following criteria specified based on the suggestions of Polit and Beck (2009).

1. Have the study's objective and the research questions been specified clearly?

2. Have the concepts mentioned in the study been defined clearly?

3. Have the characteristics of the sample been explained sufficiently?

4. Has the number of the sample been sufficient?

5. Have the instruments and methods been used convenient for the issue?

6. Have the data been analyzed by using convenient methods?

7. Has the confidence interval been provided?

8. Have the results clearly and conveniently been organized?

9. Have the results conveniently been discussed?

10. Have the discussions been compatible with results?

11. Have the limitations been specified? 
Each criterion was evaluated separately and while the studies that met the criterion were evaluated as " 1 point", the studies that did not meet the criterion were evaluated as " 0 point". We decided to exclude studies from the review if they have score below 7. As a result of the evaluation, it was obtained that the lowest score was 9 and the highest score was 11 .

\section{Data Extraction and Synthesis}

The researchers created a standard format to summarize and evaluate data pertaining to the findings (Table 3). The data evaluation format includes information such as name of authors and year of publication, publication status of the research (published article, unpublished master's or doctorate theses, etc.), city or the region where the study was carried out, type of research, research sample, data collection tool, rate of exposure to mobbing behavior, the most frequent types of mobbing behavior (top three), profile of individuals who exhibit them, effects of mobbing behavior on victims and behavior adopted to avoid mobbing.

\section{Results}

\section{Study Characteristics}

This review considers a total of 38 mobbing studies carried out on nurses or healthcare workers including nurses in Turkey, without specifying a date range (Table 3).

A review of the distribution of studies according to the date of publication reveals an increase in the number of studies performed on this topic from 2007 till 2014. The studies consist of 21 published articles in English or Turkish, 15 unpublished master's theses and 2 unpublished doctorate theses. Studies have been performed in 20 cities (24.7\% of Turkey's 81 provinces), apart from those which do not provide location details. Ankara has the highest number of studies (Efe \& Ayaz, 2010; Köse, 2010; Seyrek, 2013; Turaç \& Şahin, 2014; Ünlüsoy-Dinçer, 2010; Yıldırım, 2009), followed by Istanbul (Dilman, 2007; Fışkın, 2011; Üye, 2009; Yildirim \& Yildirim, 2007; Zonp, 2012) and Izmir (Akın-Korhan, Kocacal-Guler, Khorshid, \& Eser, 2014; Aksu \& Akyol, 2009; Ayhan, 2012; Bahçeci-Geçici \& Sağkal, 2011; Bardakçı \& Partlak-Günüşen, 2014). The majority of studies are descriptive, followed by correlative studies.

Evaluation of research samples indicates a total of 11070 individuals, 8850 of which are nurses (79.9\%). In three of the studies (Atasoy, 2010; Güven, Özcan \& Kartal, 2012; Yurdakul, Türkleş, Vefikuluçay-Yllmaz, Çelik, Şahin \& Dündar, 2011), the target group is midwifes and nurses, while the rest of the studies concentrate on nurses from various departments. Departments are mentioned in some of the studies, these being psychiatry, intensive care units. However the majority of studies do not provide this detail. Fifteen of the studies specify the organizations where the study was carried out, performed in a total of 55 hospitals (16 private hospitals, 21 hospitals under the administration of Ministry of Health and 18 university hospitals).

The most commonly used data collection tool developed by Dilek and Aytolan (2008) (Ançel, Yuva \& Gökmen-Öztuna, 2012; Ayhan, 2012; Bardakçı \& Partlak-Günüşen, 2014; Ekici \& Beder, 2014; Köse, 2010; Yildirim \& Yildirim, 2007; Seyrek, 2013; Üye, 2009; Y1ldırım, 2009; Yurdakul et al. 2011), followed by the Leymann Inventory of Psychological Terror (LIPT) developed by Leymann (1990) (Çakı1, 2011; Çınar \& Dursun, 2012; Gül \& 
Ağıröz, 2011; Kılıç, 2013; Özen-Çö1, 2008; Şahin \& Dündar, 2011; Turaç \& Şahin, 2014) (Table 3). The scales were similar when compared in light of sub categories, with negative behavior towards reputation of personality, communication in workplace, social relations and professional life chosen as basic categories. In some scales (see for example LIPT scale) behaviors affecting physical health were considered a category, while in others (see for example Öztürk, Y1lmaz and Hindistan's scale) they were evaluated as effects of mobbing. While verbal violence is examined under the communication subcategory, physical and sexual violence are directly examined among negative behavior. In a scale (Ünlüsoy-Dinçer, 2010), bullying is approached under a subcategory of psychological violence in the workplace with verbal and sexual violence.

\section{Exposure to Mobbing Behavior}

Using the scales, classification of the prevalence of exposure to mobbing behavior (at least once) results in values ranging from $0 \%$ to $100 \%$, as summarized in Table 2 .

Table 2

Prevalence of Exposure to Mobbing Behavior Classified According to Scales

\begin{tabular}{ll}
\hline Scale used & Minimum and maximum percentage \\
\hline Dilek and Aytolan's scale (2008) $(\mathrm{n}=10)$ & Minimum 21.0\%, maximum $100 \%$ \\
LIPT scale $(\mathrm{n}=7)$ & Minimum “very low", maximum $68.5 \%$ \\
Öztürk, Y1lmaz and Hindistan's scale (2007) $(\mathrm{n}=5)$ & Minimum 9.7\%, maximum $53.2 \%$ \\
Other scales and surveys $(\mathrm{n}=16)$ & Minimum average score "rarely", maximum 92.2\% \\
\hline
\end{tabular}

\section{Most Common Mobbing Behavior}

The most common types of mobbing behavior are analyzed according to each scale. In the studies where Dilek and Aytolan (2008) scale was used (Ançel et al. 2012; Ayhan, 2012; Bardakçı \& Partlak-Günüşen, 2014; Ekici \& Beder, 2014; Köse, 2010; Seyrek, 2013; Üye, 2009; Yildirim \& Yildirim, 2007; Y1ldırım, 2009; Yurdakul et al. 2011), attacking personality and professional status had the highest percentage. Considering the most common mobbing behavior in this scale, the first and second rank was humiliation in front of others (attacking personality) and controlling the victims or their jobs without being noticeable. The third rank was mostly blaming victims for issues outside their responsibilities (attacking professional status). Among other top three behavior were underestimating and belittling victim's performance, holding victims responsible for jobs exceeding their capacity (attacking professional status), exhibiting humiliating behavior or body language in front of others (attacking personality). However, in Üye's study (2009) 64\% of the victims experienced physical violence as the most common mobbing behavior. The rate of physical violence is $12.7 \%$ in the study by Yurdakul et al. (2011) (midwives and nurses), and $7.3 \%$ in the study by Yildirim and Yildirim (2007) (Table 3).

Regarding studies using the LIPT scale (Çakı1, 2011; Çınar \& Dursun, 2012; Gül \& Ağıröz, 2011; Kılıç, 2013; Özen-Çöl, 2008; Turaç \& Şahin, 2014; Şahin \& Dündar, 2011), victims were most frequently exposed to behavior preventing self-expression and communication, attacking social reputation and attacking professional status and quality of life. The most frequently observed mobbing behavior were continuous interrupting and silencing, constant criticism and refusing communication with victim (preventing communication), assigning 
responsibilities that are below the victim's abilities and requesting victim to perform meaningless works (attacking quality of life and professional status) (Table 3).

Considering the studies using Öztürk, Y1lmaz and Hindistan's scale (2007) (Akın-Korhan et al. 2014; Asi-Karakaş, 2011; Bahçeci-Geçici \& Sağkal, 2011; Demir, Bulucu, Özcan, Yılmaz \& Şen, 2014; Efe \& Ayaz, 2010), only one study indicates attack to self-esteem as the category with the highest frequency of occurrence. In the rest of the studies, apart from the abovementioned behavior (attacking personality, reputation and professional status), the most frequently experienced behavior were negative conversations among colleagues, forcing victim to quit, depriving victim of legal rights, understating victim's success, questioning professional decisions made by victim, requesting inconsistent tasks and giving groundless penalties, negatively evaluating victim's performance and criticizing victim's uniform (Table 3 ).

\section{Profile of Individuals Exhibiting Mobbing Behavior on Nurses}

Profile of the individuals who exhibit mobbing behavior has been specified in 20 studies. According to these studies, nurses experience the highest rate of mobbing behavior from their managers, ranging from $12.7 \%$ to $78.5 \%$, followed by physicians, ranging from $10.7 \%$ to $67.0 \%$, colleagues, ranging from $17.1 \%$ to $48.0 \%$ and patients' relatives, ranging from $28.5 \%$ to $42.0 \%$, respectively (Table 3 ).

\section{Effect of Mobbing Behavior on Nurses}

According to the findings of the studies, the most prominent effects of exposure to mobbing behavior are negative psychological effects. Nurses feel the negative effects on their personal lives (18.4\%- 85.2) (Aksu \& Akyol, 2009; Efe \& Ayaz, 2010; Üye, 2009), experience headaches (14.50\%-69.5\%) (Yildirim \& Yildirim, 2007; Atasoy, 2010; Yurdakul et al. 2011; Üye, 2013), feel stressful and tired (62.4\%-72.4\%) (Yildirim \& Yildirim, 2007; Yurdakul et al. 2011; Üye, 2009) and insomnia (14.1\%-37.5\%) (Arısoy, 2011; Atasoy, 2010), continuously remember their negative experiences (25.6\%-58.5\%) (Ünlüsoy-Dinçer, 2010; Yildirim \& Yildirim, 2007), and experience changes in their motivation and dedication (38.1\%) (Arısoy, 2011). The study performed by Yildirım (2009) indicates moderate depression in $45 \%$ of the nurses, and while the study of Y1ldız and Eliş-Yıldız (2009) reports evidence of extreme depression, the depression rate is $33 \%$ in the article by Ekici and Beder (2014), 16.9\% in the article by Arısoy (2011) and 5.8\% in the article by Ançel et al. (2012).

\section{Responses to Mobbing Behavior}

The responses to mobbing behavior are out of scope (N/A) in the majority of studies (Table 3 ). Examination of the behavior on the top list in the remaining of the studies $(n=17)$ reveals the following responses: sharing of incident with friends and family $(10.2 \%-83.5 \%$ ) (Aksu \& Akyol, 2009; Arısoy, 2011; Bahçeci-Geçici \& Sağkal, 2011; Bardakçı \& Partlak-Günüşen, 2014; Dilman, 2007; Efe \& Ayaz, 2010; K1lıç, 2013), working harder and with more discipline (72.1\%- 81.6\%) (Yildirim \& Yildirim, 2007; Köse, 2010; Üye, 2009), remaining silent and passive (11.6\%-60.9\%) (Aksu \& Akyol, 2009; Ançel et al. 2012; Arısoy, 2011; Bahçeci-Geçici \& Sağkal, 2011; Bardakçı \& Partlak-Günüşen, 2014; Çevik-Akyil, Tan, Sarıtaş \& Altuntaş, 2012; Demir et al. 2014; Dilman, 2007; Efe \& Ayaz, 2010; Gürkan, 2010; Kılıç, 2013; 
Somunoğlu, Gedik, Erol-Kurt, Eygi, Gebedek, İlhan, \& Sağ, 2013; Ünlüsoy-Dinçer, 2010), attempting to solve the problem by directly speaking with the individual exhibiting mobbing behavior (19.3\%-91.1\%) (Dilman, 2007; Kılıç, 2013; Üye, 2009; Yildirim \& Yildirim, 2007). Other responses in the second and third place are moving to another department $(20.4 \%$ $32.6 \%$ ) (Atasoy, 2010, Ünlüsoy-Dinçer, 2010), reporting to senior management $(25.8 \%$ 64.9\%) (Dilman, 2007; Gürkan, 2010; Yildirim \& Yildirim, 2007) and protecting themselves physically (8.8\%) (Demir et al. 2014) (Table 3). Three of the studies involved victims seriously thinking about quitting their jobs (13.9\%-61.4\%) (Somunoğlu et al. 2013; Üye, 2009; Yurdakul et al. 2011) and in three other studies victims thought about completely leaving their profession (7.3\%-56.5\%) (Aksu \& Akyol, 2009; Arısoy, 2011; Dilman, 2007). The results of three other studies indicate a portion of victims occasionally considering suicide (7\%-10.0\%) (Üye, 2009; Yildirim \& Yildirim, 2007; Yurdakul et al. 2011). Finally, the results of three studies state that 32 victims applied for legal charges (Atasoy, 2010; Bahçeci-Geçici \& Sağkal, 2011; Bardakç1 \& Partlak-Günüşen, 2014).

\section{Discussion}

Information regarding the health institutions was not specified in all of the studies. Nevertheless, it is prominent that the studies have been carried out in primary, secondary and tertiary public and private health institutions. According to Ministry of Health Statistics of 2013 (2014), Turkey's total nurse population is 139,544 . The studies cover $24.7 \%$ of Turkey's cities and $6.3 \%$ of total nurse population. The results of these, 38 studies in the past 13 years are collected from a large sample of 8,850 nurses. Three studies (Atasoy, 2010; Güven et al., 2012; Yurdakul et al., 2011) conducted with midwives and nurses working at hospitals gave the general results which were not peculiar to nurses. The results of these studies were also included as some of the midwives at hospitals were in the nursing staff and most of them worked as nurses.

Despite similarity among subcategories of different scales used in the studies, some scales question violence (with verbal, physical and sexual violence as subcategories), while others evaluate the effects of negative behavior on victim's health and private/professional life. According to the Ministry of Labor and Social Security (2014), behaviors which involve physical violence, sexual abuse and/or insult are not considered mobbing due to different legal issues and consequences associated with these actions, suggesting that terrorization and violence should be distinguished from one another.

Analysis of the incidences of mobbing behavior revealed a broad spectrum, ranging from rarely experiences to $100 \%$ experiences. In some scales the categories are formed according to the scores, in other scales the rates of exposure pertaining to at least one behavior is given and in some studies the general rate is not mentioned. Nevertheless, the percentage rates obtained from the scales generally have a broad range. On the other hand, $18 \%-37 \%$ of healthcare workers have been exposed to deliberate mobbing, and 71\%-94\% of victims have experienced one or more mobbing behavior (Davenport, Schwartz \& Elliott, 2003). In order to include a behavior in the scale as mobbing, the action must be continuous and systematic, occurring frequently and for a long period of time (The Ministry of Labor and Social Security, 2014). In this respect, the general results obtained in this study are evaluated as (at least one) exposure to mobbing behavior. 
Studies conducted on healthcare workers indicate nurses as the group experiencing the highest rate of intimidation (one of these studies involves midwives and nurses). Only one study indicates physicians as the group experiencing the highest rate of mobbing behavior (Kılıç, 2013). A compilation study carried out by Lee, Bernstein, Lee and Nokes (2014) using studies published internationally also concludes that nurses experience the most mobbing behavior among healthcare workers. These studies indicate that research on healthcare workers must be conducted with a larger sample range.

The most frequently observed mobbing behaviors in this review include attacking personality, blocking communication, attacking professional, and social reputation. Examples of these behaviors are interrupting speech, humiliating victim in front of others, continuously criticizing or controlling the victims' actions, blaming victim for redundant issues, etc. In their study, Cleary, Hunt and Hosfall (2010) ranked the most frequently encountered mobbing behavior according to the literature in the following order: giving tasks which exceed victim's workload or managing capacity, ignoring or isolating the victim, spreading rumors, assigning inferior tasks, ignoring victim's professional opinions, withholding information about tasks directly related to victim, requesting unachievable tasks or demanding unrealistic deadlines and humiliating or mocking the victim's achievements. Similarly, a systematic review by Lee et al. (2014) indicates the most frequent mobbing behavior as giving tasks which exceed victim's workload and managing capacity. Kisa (2008) declares 80\% - 97\% prevalence of verbal violence on nurses in the international literature. In the study conducted in Turkey by the same author, the rate of verbal violence was $79.4 \%$, and categorized as $66.2 \%$ criticism and $43.5 \%$ accusation and blaming. In this study the individuals exhibiting this behavior are $72.9 \%$ patient relatives, $63.9 \%$ patients and $49.1 \%$ physicians. The similarity between the type of verbal violence (criticism and accusation) and mobbing behavior is noteworthy. However, these are not considered mobbing due to lack of persistency or deliberate intimidation.

Nurses are most frequently affected by their managers, followed by physicians, colleagues and patients and their relatives. Managers are also on the top list in the systematic compilation of Lee et al. (2014). Even though the order varies in each study, nurses are mostly affected by these groups.

Patients are continuously accompanied by their relatives at hospital in Turkey and they are benefitted for treatment and care of their patients. Based on the results of Kisa's (2008) study, it can be asserted that determination of patients and their relatives as those displaying mobbing was associated with continuous togetherness and the presence of items indicating verbal violence in assessment instruments.

Mobbing behavior affects the victim's psychology, physiology and private and professional life (Cleary et al., 2010). Moreover, exposure to mobbing behavior leads to psychological problems, depression and the idea of suicide (Ekici \& Beder, 2014). Evaluation of the effects of mobbing on nurses in this review leads to psychological effect as the most common effect of mobbing. Other studies also mention victims experiencing psychological and physical health problems and exhibiting psychosomatic and severe psychological symptoms (Hallberg \& Strandmark, 2006). According to the study by Lee et al. (2014), the most common physical effects are cardiovascular symptoms such as hypertension, chest pain and palpitations and the most commonly encountered psychological effect is fear. In the studies that question 
depression as an outcome of mobbing or those that analyze the relation between depression and mobbing, nurses exhibit signs of depression at a rate of $5.8 \%-45 \%$, or to the extents which can be categorized as severe depression.

The results obtained from this review show that nurses generally keep silent against mobbing, and try to overcome the situation by working harder with the help and support of friends and family. A lower portion of victims complain, and an even lower portion (only 32 nurses) take legal actions. The reasons for keeping silent are stated as the action not being perceived as mobbing behavior, differences in reporting procedures, fear of being punished, believing there will be no change, fear of being labelled and the risk of negatively affecting their career goals (Cleary et al., 2010). Nurses who fail to deal with mobbing behavior feel less devoted, decide to quit or even leave their profession forever. In the systematic review by Lee et al. (2014), the result of mobbing has been stated as the victims' intention to quit, and the most common effect observed in this study is increased absenteeism.

According to three of the studies evaluated in this compilation, $7 \%-10 \%$ of the victims consider suicide. Similarly, in the study performed by Hallberg and Strandmark (2006) some of the victims reported thinking about suicide once they thought changing the situation was not possible. The same study refers to an article by Leymann in 1990, which estimates that 100 to 300 of the individuals who committed suicide in that year had been exposed to mobbing behavior.

Rates of nurses' exposure to mobbing are high, they are exposed to these behaviors mostly by their managers and physicians, and they keep mostly quiet about these incidents; all of which can be evaluated also in terms of cultural characteristics. Hofstede (1980) defined Turkish culture as collectivist, hierarchical, and feminine. This result show that status and hierarchy are attached importance (Hofstede, 1980). Additionally, the fact that nurses are mostly female and there is much mental workload can lead them to be vulnerable (Sönmez, Oğuz, Kutlu, \& Y1ldırım, 2017). Bullying/mobbing which has been involved in Turkish as a foreign term was defined in 2011 with legal legislation, which is thought to increase understanding and definition of the concept.

\section{Limitations}

This review was limited to 38 studies. Assessment instruments used in the studies measured mobbing and also other violence types. The fact that unpublished dissertations and studies including limited number of nurses in sample of all healthcare professionals were included in the study in order to be at national level can be accepted as a limitation. The absence of a legal regulation on mobbing in Turkey until 2011 might have led to difference in comprehending the concept and failure of reporting the incidents.

\section{Conclusions}

The findings of review of 38 studies regarding mobbing behavior on nurses or healthcare workers including nurses in Turkey concludes that nurses working in many cities are exposed to high levels of mobbing behavior, this exposure is higher than both other healthcare workers in Turkey and nurses in other countries.

Results from studies carried out with different scales indicate that nurses are exposed to similar mobbing behaviors. Even though the frequency of exposure of nurses to mobbing 
behavior is not mentioned in all studies, it can be understood from the findings that most of the behaviors have bullying nature.

Mobbing behaviors mostly lead to psychological effects in nurses, lack of motivation and feeling of exhaustion result in the decision to quit their profession and those unable to effectively cope with the issue experience high levels of depression. Only a small portion of nurses exposed to mobbing behavior have been found to react by complaining or taking legal actions.

Preventing exposure of healthcare workers to physical violence and mobbing behavior is an important global agenda. The findings of this article demonstrate that nurses are exposed to a variety of mobbing behaviors to a large amount, these being humiliation in front of others, blaming victims for irrelevant duties and others characterized by quantitative research methods.

Legal nature and preventive activities of mobbing behavior can be evaluated specifically for different countries. Even though these behaviors are not described as mobbing behavior from legal point of view, they must be considered in terms of individual and institutional consequences that adversely affect the performance of nurses. These findings will contribute to the studies that investigate the mobbing behaviors experienced by nurses on a global context or compare them between different cultures. Moreover, these studies will also be useful for international organizations that direct initiatives for the prevention of mobbing in the workplace.

In the future studies, mobbing should be examined by being distinguished from verbal, physical and sexual violence; systematic repetition of behaviors which are considered insignificant when individually examined as well as difficulties experienced by victims for proving should be clearly questioned. Additionally, it is recommended to conduct further studies for explaining the cause of mobbing. The relationship between workloads of nurses and their exposure to mobbing by their colleagues and the relationship between drug errors of nurses exposed to mobbing and negative care outcomes can be evaluated.

\section{References}

AbuAlRub, R. F., Khalifa, M. F., \& Habbib M. B. (2007). Workplace violence among iraqi hospital nurses. Journal of Nursing Scholarship, 39(3), 281-288.

Akın-Korhan, E., Kocacal-Guler, E., Khorshid, L., \& Eser, I. (2014). Mobbing experienced by nurses working in hospitals: An example of Turkey. International Journal of Caring Sciences, 7(2), 642-651.

Aksu, T., \& Akyol, A. (2009). Yoğun Bakım hemşirelerinin duygusal tacizden etkilenme durumlarının incelenmesi [Evaluation of response levels of intensive care nurses to emotional abuse]. Yoğun Bakım Hemşireliği Dergisi, 13(2), 69-76.

Ançel, G., Yuva, E., \& Gökmen-Öztuna, D. (2012). Eş-bağımlılık ve işyerinde mobing arasındaki ilişki [The relationship between co-dependency and mobbying/bullying]. Anadolu Psikiyatri Dergisi,13, 104-109.

Arısoy, A. (2011). Mobbingi ortaya çıkaran faktörler: Isparta- Antalya- Burdur'da sağlık sektöründe hemşireler üzerine çalışma [The Factors occur mobbing: The study on the nurses working at the health sector in Antalya-Burdur-Isparta] (Unpublished master's thesis). SüleymanDemirel University Institute of Social Sciences, Isparta, Turkey.

Asi-Karakaş, S. (2011). Mobbinge maruz kalan hemşirelere verilen atılganlı eğitiminin mobbingle başetmeye etkisi [The effect of assertiveness education given to nurses who are exposed to mobbing on handling mobbing] (Unpublished doctoral dissertation). Atatürk University Institute of Health Sciences, Erzurum, Turkey.

Atasoy, I. (2010). Sağllk sektöründe mobbing: Sakarya ilinde kamu ve özel hastanelerde çalışan ebe ve hemşireler üzerine bir araştırma [Mobbing in health sector a survey on nurses and midwifes working at the public and private hospitals in Sakarya] (Unpublished master's thesis). University Institute of Social Sciences, Sakarya, Turkey.

Ayhan, G. (2012). Hemşirelerde psikolojik şiddet (mobbing) ile atılganlık düzeyi ilişkisi [The relationship between psychological violence (mobbing) and levels of assertiveness] (Unpublished master's thesis). Ege University Institute of Health Sciences, Izmir, Turkey. 
Bahçeci-Geçici, N., \& Sağkal, T. (2011). Ödemiş’te çalışan hemşirelerin mobbinge maruz kalma durumlarının incelenmesi [A survey about the state of nurses who experienced mobbing in Ödemis]. Maltepe Üniversitesi Hemşirelik Bilim ve Sanatı Dergisi, 4(1), 53-62.

Bardakçı, E., \& Partlak-Günüşen, N. (2014). Influence of workplace bullying on turkish nurses' psychological distress and nurses' reactions to bullying. Journal of Transcultural Nursing, 1-6. doi: 10.1177/1043659614549073.

Cleary, M., Hunt, G. E., \& Hosfall, J. (2010). Identifying and addressing bullying in nursing. Issues in Mental Health Nursing, 31,331-335.doi: 10.3109/01612840903308531.

Çak1l, E. (2011). Üniversite hastanesinde çalışan hemşire ve asistanlarda mobbing'in işe gönülden adanma üzerine etkisi [The effect of mobbing on work engagement for the nurses and assistant doctors work for an university hospital] (Unpublished master's thesis). ZKU Institute of Social Sciences, Zonguldak, Turkey.

Çevik-Akyil, R., Tan, M., Sarıtaş, S. W., \& Altuntaş, S. (2012). Levels of mobbing perception among nurses in Eastern Turkey. International Nursing Review,59, 402-408. doi: 10.1111/j.1466-7657.2012.00974.x

Çınar, O., \& Dursun, A. (2012). Mobbing, örgütsel bağl1lık ve iș tatmini ilişkisi: Atatürk Üniversitesi Araştırma Hastanesinde yapılan bir alan araştırması [The relationship between mobbing, commitment and job satisfaction: A survey study in the Research Hospital of Ataturk University]. Ekev Akademi Dergisi, 16(52), 319-338.

Davenport, N. Z., Schwartz, R. D., \& Elliott, G. P. (2003). Mobbing, emotional abuse in the American workplace. [Translated by Osman CemÖnertoy]. Istanbul, Turkey: SistemYayıncılık.

Demir, G., Bulucu, G. D., Özcan, A., Yılmaz, D., \& Şen, H. (2014). Hemşirelerin mobbinge uğrama durumlarının belirlenmesi [A survey about the state of nurses who experienced mobbing]. Düzce Üniversitesi Sağllk Bilimleri Enstitüsü Dergisi,4(1), $1-5$.

Dilek Y., \& Aytolan Y. (2008) Development and psychometric evaluation of workplace psychologically violent behaviours instrument. Journal of Clinical Nursing, 17, 1361-1370.

Dilman, T. (2007). Özel hastanelerde çalışan hemşirelerin duygusal tacize maruz kalma durumlarının belirlenmesi [Defining the situation of mobbing experience among the nurses working in private hospitals] (Unpublished master's thesis). Marmara University Institute of Health Sciences, Istanbul, Turkey.

Efe, S. Y., \& Ayaz, S. (2010). Mobbing against nurses in the workplace in Turkey. International Nursing Review, 57, 328-334. doi: 10.1111/j.1466-7657.2010.00815.x

Ekici, D., \& Beder, A. (2014). The effects of workplace bullying on physicians and nurses. Australıan Journal of Advanced Nursing,31(4), 24-33.

Fışkın, G. (2011). Mobbing davranışı ve ana çocuk sağlı̆̆ı merkezlerindeki sağlık çalışanlarına yönelik bir araştırma [A study on mobbing behaviour, aimed at the medical staff employed in the centers for maternal and infant healthcare] (Unpublished master's thesis). Istanbul University, Institute of Health Sciences, Istanbul, Turkey.

Fornès, J., Cardoso, M., Castello, J. M., \& Gili, M. (2011). Psychological harassment in the nursing workplace: An observational study. Archives of Psychiatric Nursing,25(3), 185-194. doi: 10.1016/j.apnu.2010.08.008.x

Gül, H., \& Ağıröz, A. (2011). Mobbing ve örgütsel sinizm arasındaki ilişkiler: hemşireler üzerinde bir uygulama [Relations between mobbing and organizational cynicism: an application on nurses]. Afyon Kocatepe Üniversitesi, IIIBF Dergisi,8(2), $27-47$.

Gürkan, K.P. (2010). Şanlıurfa'da çalışan hemşire, ebe ve sağlık memurlarının psikolojik şiddete (mobbing) maruz kalma durumlart ve ilișkili faktörler [The cases in which nurses, obstetricians and health officers in Sanliurfa face with mobbing and related factors] (Unpublished master's thesis). Harran University Institue of Health Sciences, Sanliurfa, Turkey.

Güven, D. Ş., Özcan, A., \& Kartal, B. (2012). Nevşehir il merkezinde kamuya bağlı sağlik kuruluşlarında çalışan ebe ve hemşirelerin mobbing'e uğrama durumları [Nurses and midwifes who are being mobbed in Nevsehir city centre health organizations of state]. Balıkesir Sağglk Bilimleri Dergisi,1(3), 117-123.

Hallberg, L., \& Strandmark, K. M. (2006). Health consequences of workplace bullying: experiences from the perspective of employees in the public service sector. International Journal of Qualitative Studies on Health and Well-being, 1, 109-119. doi:10.1080/17482620600555664

Hofstede, G. (1980). Motivation, leadership, and organization: Do american theories apply broad? Organizational Dynamics, $9(1), 42-63$.

Hutchinson, M., Wilkes, L., Jackson, D., \& Vickers, M. H. (2010). Integrating individual, work group and organizational factors: Testing a multidimensional model of bullying in the nursing workplace. Journal of Nursing Management, 18(2), $173-81$

Johnson, S. L. (2009). International perspectives on workplace bullying among nurses: A review. International Nursing Review, 56, 34-40. doi: 10.1111/j.1466-7657.2008.00679.x.

Kaya, E. (2010). Hemșirelerin verimliliğini düşüren iș yerindeki psikolojik (mobbing) koșullar üzerine bir inceleme; "Cumhuriyet Unniversitesi Araştırma Hastanesi örneği" [An investigation about the mobbing in the work place that 
decreases "Cumhuriyet University Research hospital case"] (Unpublished master's thesis). Cumhuriyet University Institute of Social Sciences, Sivas, Turkey.

Kılıç, N. (2013). Sağlık çalı̧̧anlarında mobbing algısı ve iş doyumunun belirlenmesi [Determining mobbing perceptions and job satisfaction among healthcare professionals] (Unpublished master's thesis). Cumhuriyet University Institute of Health Sciences, Sivas, Turkey.

Kısa, S. (2008). Turkish nurses' experiences of verbal abuse at work. Archives of Psychiatric Nursing,22(4), 200-207. doi: 10.1016/j.apnu.2007.06.013.

Köse, E. (2010). Bir üniversite hastanesinde hekim ve hemşirelerin alglladlkları örgüt kültürünün mobbing davranışlarına etkisi [In a university hospital, the effect of the doctors and nurses perception of organization culture on mobbing behavior] (Unpublished master's thesis). Gazi University Institute of Health Sciences, Ankara, Turkey.

Lee, Y. L., Bernstein, K., Lee, M., \& Nokes, K. M. (2014). Bullying in the nursing workplace: Applying evidence using a conceptual framework. Nursing Economics, 32(5), 255-267. doi.org/10.4040/jkan.2014.44.2.209.x

Leymann, H. (1990). Mobbing and psychological terror at workplace. Violence and Victims, 5, 119-126.

Özen-Çöl, S. (2008). İşyerinde psikolojik şiddet:hastane çalışanları üzerinde bir araştırma [Psychological violence at workplace: A survey of hospital staff]. Çalışma ve Toplum, 4, 107-134.

Öztürk, H., Yılmaz, F., \& Hindistan, S. (2007) Hemşireler için mobbing ölçegi ve hemşirelerin yaşadığı mobbing [A survey about the state of nurses who experienced mobbing]. Hastane Yönetimi,11(1-2), 63-69.

Polit, D. F., \& Beck, C. T. (2009). Literature reviews: Finding and reviewing research evidence. In D. F. Poli \& B. C. Tatano (Eds.), Essentails of Nursing Research:Appraising Evidence for Nursing Practice $7^{\text {th }}$ ed (pp. 169-193). Philadelphia: Lippincott Williams \& Wilkins.

Quine, L. (2001). Workplace bullying in nurses. Journal of Health Psychology, 6(1), 73-84.

Republic of Turkey, Ministry of Health Statistics, 2013 Yearbook (2014). http://ekutuphane.sagem.gov.tr/kitaplar/healht statistics yearbook 2013.pdf (accessed on 21.10.2017)

Seyrek, H. (2013). Hemşirelerde adalet algısının mobbing davranışları üzerine etkisi [Effect on the perception of justice, mobbing behavior of nurses] (Unpublished master's thesis). Gazi University Institute of Health Sciences, Ankara, Turkey.

Simon, S. (2008). Workplace bullying experienced by Massachusetts registered nurses and the relationship to intention to leave the organization. Advances in Nursing Science, 31(2), 48-59.

Solakoğlu, İ. (2007). İşletmelerde mobbingin örgütsel stresle ilişsisi ve bir sağllk kuruluşunda uygulama [Relationship between mobbing at workplace and organizational stress, and application toa Health Institute] (Unpublished master's thesis). Dumlupinar University Institute of Social Sciences, Kütahya, Turkey.

Somunoğlu, S., Gedik, A., Erol-Kurt, D., Eygi, G., Gebedek, Ş., İlhan, Y., \& Sağ, Z. (2013). Mobbing in health sector: Sample of university hospital. Journal of Health Management, 15(2), 169-17. doi: 10.1177/0972063413489003.x.

Sönmez, B., Oğuz, Z., Kutlu, L. \& Yıldırım, A. (2017), Determination of nurses' mental workloads using subjective methods. Journal of Clinical Nursing, 26(2, 3), 514-523.

Şahin, B., \& Dündar, T. (2011). Sağlık sektöründe etik iklim ve yıldırma (mobbing) davranışları arasındaki ilișkinin incelenmesi [Investigation of relationship among ethical climate and mobbing behavior in healthcare sector]. Ankara Üniversitesi Sağlık Bilimleri Dergisi, 66(1), 129-159.

The Ministry of Labor and Social Security (2014). Issyerlerinde Psikolojik Taciz (Mobbing) Bilgilendirme Rehberi [Psychological Harassment in the Workplace (Mobbing) Information Guide, 2nd edition). Ankara. https://www.csgb.gov.tr/media/2053/mobbing 2014.pdf (accessed on 29 March 2017).

The Prime Minister Circular (Number: 27879) (2011). İsyerlerinde Psikolojik Tacizin (Mobbing) Önlenmesi [Prevention of Psychological Harassment (Mobbing) in the Workplace]. http://www.resmigazete.gov.tr/main.aspx?home=http://www.resmigazete.gov.tr/eskiler/2011/03/20110319.htm\&main=http:/ /www.resmigazete.gov.tr/eskiler/2011/03/20110319.htm (accessed on 21.10.2017)

Turaç, İ. K., \& Şahin, B. (2014). Mobbinge maruz kalma durumunun belirlenmesi: Hemşireler üzerine bir çalışma [Determining the state of being subject to mobbing: A study on nurses]. Eskişehir Osmangazi Üniversitesi Sosyal Bilimler Dergisi, 15(1), 87-112.

Ünlüsoy-Dinçer, N. (2010). Hemşirelerin işyerinde şiddete maruz kalma durumlart ile iş doyumlarl ve işten ayrllma eğilimleri [The violence on nurses at workplace and the tendency to leave the job and job satisfaction of nurses] (Unpublished doctoral dissertation). Hacettepe University, Institute of Health Science, Ankara, Turkey.

Üye, C. (2009). Hemşirelerin yöneticileri tarafindan mobbing davranışları ile karşılaşma durumlarının belirlenmesi [Defining the situation of mobbing experience among the nurses by their managers] (Unpublished master's thesis). Haliç University Institute of Health Sciences, Istanbul, Turkey. 
Yildırım, D. (2009). Bullying among nurses and its effects. International Nursing Review,56, 504-511.doi: 10.1111/j.14667657.2009.00745.x.

Yıldız, S., \& Eliş-Yıldız, S. (2009). Bullying ve depresyon arasındaki ilişki: Kars ilindeki sağlık çalışanlarında bir araştırma [Correlation between bullying and depression: a research on health persons in Kars]. İstanbul Ticaret Üniversitesi Sosyal Bilimler Dergisi, 8(15),133-150.

Yılmaz, E. (2013). Mobbing davranışı ve Bandirma ili kamu hastaneleri çalışanlarına yönelik bir araştırma [Mobbing behavior and Bandırma province public hospitals survey for employees] (Unpublished master's thesis). Okan University Institute of Health Sciences, Istanbul, Turkey.

Yılmazel, G. (2013). Hemşirelerde psikolojik yıldırma, iş doyumu ve etkileyen faktörler [Mobbing, job satisfaction and affecting factors in the nurses]. Turkiye Klinikleri J Nurs Sci, 5(2), 55-63.

Yildirim, A., \& Yildirim, D. (2007). Mobbing in the workplace by peers and managers: Mobbing experienced by nurses working in the healthcare facilities in Turkey and its effects on nurses. Journal of Clinical Nursing, 1444-1452. doi: $10.1111 /$ j.1365-2702.2006.01814.x

Yurdakul, M., Türkleş, S., Vefikuluçay-Yılmaz, D., Çelik, T., Şahin, M., \& Özcan, A. (2011). Ebe ve hemşirelerin iş yerinde karşılaştıkları psikolojik bezdirme davranışları [Workplace psychological intimidation behavior encountered by midwives and nurses]. Hemşirelikte Araştırma Geliştirme Dergisi (HEMARG-E),3, $28-41$.

Zonp, Z. (2012). Psikiyatri kliniklerinde çalışan hemşirelerin mobbing algılarl ve ilişkili faktörler [Mobbing perceptions of nurses working in psychiatric clinics and related factors] (Unpublished master's thesis). Istanbul University, The Institute of Health Sciences, Istanbul, Turkey. 
Results of Mobbing Prevalence Researches Included in this Study

\begin{tabular}{|c|c|c|c|c|c|c|c|c|c|}
\hline $\begin{array}{c}\text { Author } \\
\text { (Year of } \\
\text { publication) } \\
\text { Publication type }\end{array}$ & Study design & Location & Sample & Mobbing prevalence & Most common mobbing behavior & Individuals exhibiting mobbing behavior & Effects of mobbing behavior & Reactions to mobbing behavior & $\begin{array}{l}\text { Quality } \\
\text { assessme } \\
\text { nt score }\end{array}$ \\
\hline \multicolumn{10}{|c|}{ Data collection tool: Scale developed by Dilek \& Aytolan (2008) } \\
\hline $\begin{array}{l}\text { Yildirim \& } \\
\text { Yildirim (2007) } \\
\text { Article }\end{array}$ & $\begin{array}{l}\text { Descriptive/ } \\
\text { Cross-sectional }\end{array}$ & Istanbul & $\begin{array}{l}\text { Nurses two public and four } \\
\text { private hospitals ( }(n=505)\end{array}$ & $\begin{array}{l}86.5 \% \text { of nurses (in the past } \\
12 \text { months) }\end{array}$ & $\begin{array}{l}\% 55.2 \text { humiliating victim in front of others, } 50.5 \% \\
\text { blaming victims for issues outside their responsibilities, } \\
50.1 \% \text { controlling victims or their jobs without being } \\
\text { noticeable }\end{array}$ & $\begin{array}{l}\text { Every mobbing behavior evaluated separately. } \\
\text { Results for " "humiliating victim in front of } \\
\text { others": } \\
4.1 \% \text {. } 5 \text { supervisors, } 17.1 \% \text { colleagues, } \\
.1 \% \text { physicians, } 3.0 \% \text { subordinates }\end{array}$ & $\begin{array}{l}\text { Mostly physiological and emotional } \\
\text { reactions (feeling tired and stressed) } \\
(72.9 \%) \text {, experiencing headaches } \\
(53.5 \%) \text {, continuously remember their } \\
\text { negative experiences }(58.5 \%)\end{array}$ & $\begin{array}{l}72.1 \% \text { work harder and with more discipline, } \\
70.5 \% \text { work more carefully to avoid criticism, } \\
67.3 \% \text { attempt to solve the problem by directly } \\
\text { speaking with the individual } 5.4 \% \text { report to } \\
\text { superiors, } 10.0 \% \text { occasionally think about suicide }\end{array}$ & 11 \\
\hline $\begin{array}{l}\text { Yildirım (2009) } \\
\text { Article }\end{array}$ & $\begin{array}{l}\text { Cross-sectional/ } \\
\text { Descriptive }\end{array}$ & Ankara & $\begin{array}{l}\text { Nurses in a training } \\
\text { hospital (n=286) }\end{array}$ & $\begin{array}{l}21 \% \text { of nurses (in the past } 12 \\
\text { months) }\end{array}$ & $\begin{array}{l}56 \% \text { humiliating victim in front of others, } 49 \% \\
\text { controlling victims or their jobs without being noticeable, } \\
48 \% \text { blaming victims for issues outside their } \\
\text { responsibilities }\end{array}$ & $\begin{array}{l}\text { Every mobbing behavior evaluated separately. } \\
\text { Results for " "humiliatingn victim in front of } \\
\text { others": } 40.0 \% \text { supervisors, } 34.0 \% \text { colleagues, } \\
5.0 \% \text { subordinates }\end{array}$ & $\begin{array}{l}45 \% \text { of nurses exhhibit moderate or } \\
\text { severe depression symptoms }\end{array}$ & - & 11 \\
\hline $\begin{array}{c}\text { Köse (2010) } \\
\text { Master's thesis }\end{array}$ & $\begin{array}{l}\text { Descriptive/ } \\
\text { Correlational }\end{array}$ & Ankara & $\begin{array}{c}\text { Nurses and physicians in } \\
\text { public and private hospitals } \\
(\mathrm{n}=586), 47=3 \% \text { nurses } \\
(\mathrm{n}=277)\end{array}$ & $\begin{array}{l}90 \% \text { of nurses (at least once } \\
\text { in the last year) }\end{array}$ & $\begin{array}{c}81 \% \text { attacking professional status, } \\
74 \% \text { attacking personality, } \\
60 \% \text { issalatin victim from workplace, } \\
13 \% \text { direct negative behavior }\end{array}$ & 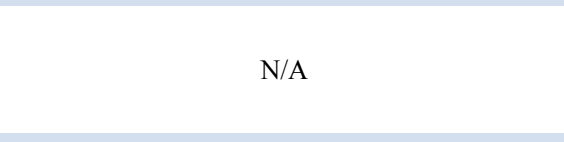 & C & N/A & 10 \\
\hline $\begin{array}{l}\text { Yurdakul et } \\
\text { al. (2011) } \\
\text { Article }\end{array}$ & Descriptive & $\begin{array}{l}\text { A city in } \\
\text { Turkey's } \\
\text { Mediterran } \\
\text { ean region }\end{array}$ & $\begin{array}{l}\text { Nurses and midwives in } \\
\text { public and private hospitals } \\
(\mathrm{n}=442)\end{array}$ & $\begin{array}{l}27.4 \% \text { of midwives, } 20.7 \% \\
\text { of nurses }\end{array}$ & $\begin{array}{l}65.4 \% \text { humiliating victim in front of others, } \\
49.5 \% \text { understating victim's performance, } \\
47.1 \% \text { blaming victims for issues outside their } \\
\text { responsibilities } \\
\text { Rate of physical violence } 12.7 \%\end{array}$ & $\begin{array}{l}\text { Every mobbing behavior evaluated separately. } \\
\text { Results for " "humiliating victim in front of } \\
\text { others" } 30.8 \% \text { physicians, } 28.5 \% \text { patient } \\
\text { relatives, } 24.2 \% \text { supervisors }\end{array}$ & $\begin{array}{l}\text { Mostly psycho-physiological and } \\
\text { emotional reactions (feeling tired and } \\
\text { stressed) (62.4\%), feeling extreme } \\
\text { sadness while recalling negative } \\
\text { behavior }(62.2 \%) \text {, } \\
\text { experiencing headaches }(58.6 \%)\end{array}$ & $\begin{array}{l}73.8 \% \text { work harder and with more discipline, } \\
72.4 \% \text { work more carefully to avoid criticismm, } \\
36.4 \% \text { seriously consider quitting, } 7.5 \% \\
\text { occasionally think about suicide }\end{array}$ & 11 \\
\hline $\begin{array}{l}\text { Ancel et al. } \\
(2012) \\
\text { Article }\end{array}$ & Descriptive & $\begin{array}{c}\text { Not } \\
\text { mentioned }\end{array}$ & $\begin{array}{l}\text { Nurses in a university } \\
\text { hospital }(\mathrm{n}=199)\end{array}$ & $63 \%$ of nurses & (20 & $\mathrm{N} / \mathrm{A}$ & Depression rate: $5.8 \%$ & $\begin{array}{l}\text { Hiding out, not expressing oneself, } \\
\text { being unable to express negative feelings and } \\
\text { thoughts }\end{array}$ & 9 \\
\hline $\begin{array}{l}\text { Ayhan (2012) } \\
\text { Master's } \\
\text { thesis }\end{array}$ & $\begin{array}{l}\text { Descriptive/ } \\
\text { Correlational }\end{array}$ & Izmir & $\begin{array}{l}\text { Nurses in Dokuz Eylul } \\
\text { University Faculty of } \\
\text { Medicine Hospital(n=472) }\end{array}$ & $52.1 \%$ of nurses & $\begin{array}{l}\text { 73.7\% indirectly controlling victims or their jobs without } \\
\text { being noticeable, } 00.6 \% \text { oblaming victims for issues } \\
\text { outside their responsibilities, } 60 \% \text { ofhlding victims } \\
\text { responsible for jobs exceeding their capacity }\end{array}$ & N/A & N/A & N/A & 11 \\
\hline $\begin{array}{c}\text { Üye (2009) } \\
\text { Master's thesis }\end{array}$ & $\begin{array}{l}\text { Cross-sectional/ } \\
\text { Descriptive }\end{array}$ & Istanbul & $\begin{array}{l}\text { Nurses in three hospitals in } \\
\text { the Asian region of } \\
\text { Istanbul: one private, one } \\
\text { public and one university } \\
\text { hospital (n=272) }\end{array}$ & $\begin{array}{l}\text { Every nurse participating in } \\
\text { the study } \\
\text { (in the last year) }\end{array}$ & $\begin{array}{l}64 \% \text { physical violence, } \\
63.6 \% \text { humiliation in front of others, } \\
62.1 \% \text { blaming victims for issues outside their } \\
\text { responsibilitites, } 57 \% \text { negative conversations regarding } \\
\text { victims, } 56.6 \% \text { holding victim responsible for negative } \\
\text { results of whole team }\end{array}$ & Supervisors & $\begin{array}{l}72.4 \% \text { feeling tired and stressed, } \\
6.5 \% \text { experiencing headaches } \\
62.9 \% \text { experiencing negative effects } \\
\text { in private life } \\
61 \% \text { feeling extreme sadness while } \\
\text { recalling negative behavior } \\
59.9 \% \text { losing trust in colleagues }\end{array}$ & $\begin{array}{l}81.6 \% \text { work harder and more systematically, } \\
79.4 \% \text { work more carefully to avoid criticism, } \\
77.4 \% \\
\text { attempt to solve the problem by directly speaking } \\
\text { with the individual. } 61.4 \% \text { of nurses seriously } \\
\text { consider quitting, } 7 \% \text { occasionally 10consider } \\
\text { suicide }\end{array}$ & 10 \\
\hline $\begin{array}{r}\text { Seyrek (2013) } \\
\text { Master's thesis }\end{array}$ & Descriptive & Ankara & $\begin{array}{l}\text { Nurses in one university } \\
\text { hospital and one private } \\
\text { hospital (n=250) }\end{array}$ & $\begin{array}{l}28 \% \text { of nurses have at least } \\
\text { one experience }\end{array}$ & $\begin{array}{l}43 \% \text { behavior attacking professional status, } \\
28 \% \text { bohavior attacking personality } \\
23 \% \text { behavior aimed to isolate victim }\end{array}$ & N/A & N/A & N/A & 10 \\
\hline $\begin{array}{l}\text { Bardakç \& } \\
\text { Partlak- } \\
\text { Güniusen } \\
\text { (2014) } \\
\text { Article }\end{array}$ & Descriptive & Izmir & $\begin{array}{l}\text { Nurses in university } \\
\text { hospital (n=284) }\end{array}$ & $21.8 \%$ of nurses & 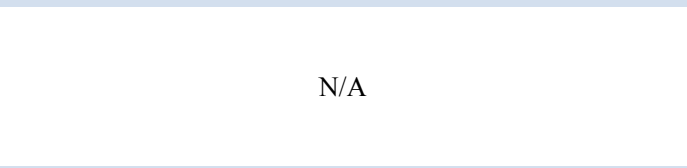 & $\begin{array}{c}33.5 \% \text { supervising nurses, } 26.8 \% \text { physicians, } \\
17.7 \% \text { colleagues, } \\
17.1 \% \text { senior nurses, } \\
4.9 \% \text { assisting personnel }\end{array}$ & N/A & $\begin{array}{l}47.3 \% \text { remain silent, } 32.4 \% \text { share incident with } \\
\text { friends and family, } 30.6 \% \text { ignore the individual. } \\
1.8 \% \text { of nurses }(\mathrm{n}=5) \text { applied for legal charges }\end{array}$ & 10 \\
\hline $\begin{array}{l}\text { Ekici\&Beder } \\
\text { (2014) } \\
\text { Article }\end{array}$ & $\begin{array}{l}\text { Cross-sectional } \\
\text { / Descriptive }\end{array}$ & $\begin{array}{c}\text { Not } \\
\text { mentioned }\end{array}$ & $\begin{array}{l}\text { Physicians }(\mathrm{n}=201) \text { and } \\
\text { nurses }(\mathrm{n}=309) \text { in a } \\
\text { university hospital }\end{array}$ & $\begin{array}{l}82 \% \text { of nurses, } 74 \% \text { of } \\
\text { physicians (in the last year) }\end{array}$ & $\begin{array}{l}\text { Most frequent behavior include humiliation in front of } \\
\text { others (attacking personality) and indirectly controlling } \\
\text { victims or their jobs without being noticeale and blaming } \\
\text { victims for issues outside their responsibilities (attacking } \\
\text { professional status) }\end{array}$ & $\begin{array}{l}\text { Both physicians and nurses experience } \\
\text { mobbing from supervisors and colleagues }\end{array}$ & $\begin{array}{l}\text { Negative effect on dedication and } \\
\text { relationship with patients (p<0.01) } \\
\text { According to regression analysis, } \\
\text { influence of mobbing on depression } \\
\text { symptoms is } 33 \% \text {, whereas influence } \\
\text { of workload is } 30 \%\end{array}$ & $\mathrm{~N} / \mathrm{A}$ & 10 \\
\hline \multicolumn{10}{|c|}{ Data collection tool: LIP developed by Leymann (1990) } \\
\hline $\begin{array}{l}\text { Özen-Çöl (2008) } \\
\text { Article }\end{array}$ & Descriptive & Muğla & $\begin{array}{c}\text { Health care workers in } \\
\text { public and private sectors } \\
(\mathrm{n}=272), 29.2 \% \text { nurses } \\
(\mathrm{n}=78)\end{array}$ & $\begin{array}{l}34.9 \% \text { of health care } \\
\text { workers, } 35.9 \% \text { of nurses }\end{array}$ & $\begin{array}{l}39 \% \text { criticizing victim's performance, } 22.1 \% \text { not caring } \\
\text { about victim's personality or presence, } 22.1 \% \text { assigning } \\
\text { responsibilitities that are below the victim's competency }\end{array}$ & N/A & N/A & N/A & 11 \\
\hline $\begin{array}{l}\text { Cakil (2011) } \\
\text { Master's } \\
\text { thesis }\end{array}$ & $\begin{array}{l}\text { Descriptive/ } \\
\text { Correlational }\end{array}$ & Zonguldak & $\begin{array}{l}\text { Nurres and assistant } \\
\text { physicians in Zonguldak } \\
\text { Karaelmas University } \\
\text { Hospital ( } \mathrm{n}=2644), 67 \% \\
\text { nurses }(\mathrm{n}=177)\end{array}$ & $40.8 \%$ of nurses & $\begin{array}{l}\text { Depriving victim of any means of communication } \\
(x=2.01) \text {, preventing self-expression }(x=1.90) \\
\text { continuous interrupting and silencing }(x=1.85)\end{array}$ & $\begin{array}{l}61.6 \% \text { superiors, } \\
28.8 \% \text { colleagues, } \\
9.6 \% \text { subordinates }\end{array}$ & N/A & $\mathrm{N} / \mathrm{A}$ & 10 \\
\hline $\begin{array}{l}\text { Sahin\&Dindar } \\
\text { (2011) } \\
\text { Article }\end{array}$ & Descriptive & Bolu & $\begin{array}{c}\text { Healthcare workers in } \\
\text { public and private hospitals } \\
(\mathrm{n}=514), 38.5 \% \text { nurses } \\
(\mathrm{n}=198)\end{array}$ & $\begin{array}{l}70.4 \% \text { of health care } \\
\text { workers, } 65 \% \text { of nurses (at } \\
\text { least one intimidation } \\
\text { experience) }\end{array}$ & $\begin{array}{l}77.7 \% \text { limiting means of communication and self- } \\
\text { manifestation, } 62.1 \% \text { attacking social reputation, } 53 \% \\
\text { attacking quality and life and professional status. }\end{array}$ & N/A & N/A & N/A & 10 \\
\hline $\begin{array}{l}\text { Gül\&Ağgrözz } \\
\text { (2011) } \\
\text { Article }\end{array}$ & $\begin{array}{l}\text { Descriptive/ } \\
\text { Correlational }\end{array}$ & Karaman & $\begin{array}{l}\text { Nurses in Karaman Public } \\
\text { Hospital (n=107) }\end{array}$ & $\begin{array}{l}\text { No significant experience } \\
(2.1829 \pm 0.73142)\end{array}$ & N/A & $\mathrm{N} / \mathrm{A}$ & N/A & N/A & 11 \\
\hline
\end{tabular}




\begin{tabular}{|c|c|c|c|c|c|c|c|c|c|}
\hline $\begin{array}{l}\text { Cinar\&Durs } \\
\text { un (2012) } \\
\text { Article }\end{array}$ & Correlational & Erzurum & $\begin{array}{l}\text { Nurses in Ataturk } \\
\text { University Hospital } \\
(\mathrm{n}=198)\end{array}$ & Very low levels $(1.34 \pm 0.330)$ & N/A & N/A & N/A & N/A & 10 \\
\hline $\begin{array}{l}\text { Killç (2013) } \\
\text { Master's thesis }\end{array}$ & Descriptive & Kars & $\begin{array}{l}\text { Health professionals in } \\
\text { various health institutions } \\
\text { in city center }(\mathrm{n}=390), \\
33.6 \% \text { nurses }(\mathrm{n}=116)\end{array}$ & 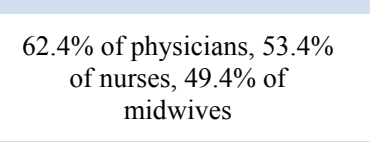 & 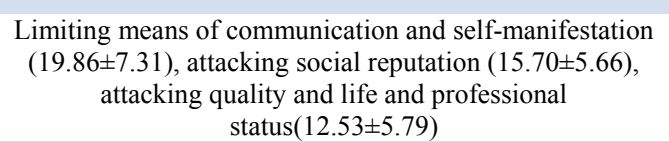 & N/A & N/A & $\begin{array}{l}33.8 \% \text { share incident with friends, } 19.3 \% \text { attempt } \\
\text { to solve the problem by directly speaking with the } \\
\text { individual, } 19.3 \% \text { do nothing }\end{array}$ & 10 \\
\hline
\end{tabular}

\section{Data collection tool: Scale developed by Öztürk, YIImaz and Hindistan (2007)}

\begin{tabular}{|c|c|c|c|c|c|c|c|c|c|}
\hline $\begin{array}{l}\text { Efe\&Ayaz } \\
(2010) \\
\text { Article }\end{array}$ & $\begin{array}{l}\text { Mix study } \\
\text { Descriptive } \\
\text { /Phenomenolo } \\
\text { gical }\end{array}$ & Ankara & $\begin{array}{l}\text { Nurses in a training } \\
\text { hospital }(n=206)\end{array}$ & $\begin{array}{l}9.7 \% \text { according to scale } \\
\text { results, 33\% according to } \\
\text { personal interview results }\end{array}$ & $\begin{array}{l}\text { Creating stress by assigning multiple tasks or exhibiting } \\
\text { humiliating behavior (according to focus group } \\
\text { feedbacks) }\end{array}$ & $\begin{array}{l}25.2 \% \text { head nurses, } \\
19.4 \% \text { physicians, } \\
9.7 \% \text { clinic chiefs }\end{array}$ & $\begin{array}{l}\text { 18.4\% feel unhappy in private life, } \\
15.05 \% \text { experience psychological } \\
\text { problems } 15.05 \% \text { have lower work } \\
\text { performance }\end{array}$ & $\begin{array}{l}11.6 \% \text { do nothing, } 11.2 \% \text { do not reply, } 10.2 \% \text { share } \\
\text { the experience with a friend }\end{array}$ & 10 \\
\hline $\begin{array}{l}\text { Bahçeci- } \\
\text { Geçici\&Sağk } \\
\text { al (2011) } \\
\text { Article }\end{array}$ & $\begin{array}{c}\text { Cross- } \\
\text { sectional/ } / \\
\text { Descriptive }\end{array}$ & $\begin{array}{l}\text { Izmir/ } \\
\text { Ödemiş }\end{array}$ & $\begin{array}{l}\text { Nurses in public and } \\
\text { private hospitals }(\mathrm{n}=128)\end{array}$ & $\begin{array}{c}43 \% \text { experienced mobbing } \\
\text { throughout professional } \\
\text { career, } 34.5 \% \text { still experience } \\
\text { mobbing }\end{array}$ & $\mathrm{N} / \mathrm{A}$ & $\begin{array}{l}32.8 \% \text { superiors, } \\
\text { 35.2\%other healthcare members } \\
\text { (physicians, dietitians, etc.) }\end{array}$ & N/A & $\begin{array}{l}26.6 \% \text { share with family and friends, } 25.7 \% \text { remain } \\
\text { silent } \\
5.5 \% \text { of nurses (n=7) applied for legal charges }\end{array}$ & 10 \\
\hline $\begin{array}{c}\text { Asi-Karakas } \\
\text { (2011) } \\
\text { Doctoral thesis }\end{array}$ & $\begin{array}{c}\text { One Group } \\
\text { Pretest- } \\
\text { Posttest Study }\end{array}$ & Erzurum & $\begin{array}{l}\text { Nurses in Ataturk } \\
\text { University Yakutiye } \\
\text { Research Hospital and } \\
\text { training and research } \\
\text { hospitals in the region Out } \\
\text { of } 218 \text { nurses, nurses with } \\
204 \text { points or higher } \\
\text { experienced mobbing } \\
(n=38)\end{array}$ & $\begin{array}{l}\text { 17.4\% of nurses (Total scale } \\
\text { score of } 204 \text { and higher) }\end{array}$ & $\mathrm{N} / \mathrm{A}$ & $\mathrm{N} / \mathrm{A}$ & $\mathrm{N} / \mathrm{A}$ & $\mathrm{N} / \mathrm{A}$ & 11 \\
\hline $\begin{array}{l}\text { Akn-Korhan et } \\
\text { al. (2014) } \\
\text { Article }\end{array}$ & Descriptive & Izmir & $\begin{array}{l}\text { Nurses in } 5 \text { public and } 2 \\
\text { university hospitals with } \\
\text { bed capacity }>500 \\
(\mathrm{n}=282)\end{array}$ & $\begin{array}{l}\text { Total scale point of } \\
161.98 \pm 45.04 \text { (moderate } \\
\text { levell } 53.2 \% \text { o f nurses } \\
\text { experience mobbing and } \\
46.7 \% \text { have experienced } \\
\text { mobbing in the first year of } \\
\text { career }\end{array}$ & $\mathrm{N} / \mathrm{A}$ & $\begin{array}{l}48 \% \text { colleagues, } \\
36 \% \text { supervisors, } \\
16 \% \text { subordinates }\end{array}$ & N/A & $\mathrm{N} / \mathrm{A}$ & 10 \\
\hline $\begin{array}{l}\text { Demir et al. } \\
\text { (2014) } \\
\text { Article }\end{array}$ & Descriptive & Düzce & $\begin{array}{l}\text { Nurses in a university } \\
\text { hospital }(\mathrm{n}=126)\end{array}$ & $\begin{array}{l}\text { Average scale point: } \\
154.60 \pm 48.66, \\
11.9 \% \text { experienced mobbing }\end{array}$ & $\mathrm{N} / \mathrm{A}$ & $\begin{array}{l}12.7 \% \text { supervisors, } \\
7.1 \% \text { nurses from the same department }\end{array}$ & $\mathrm{N} / \mathrm{A}$ & $\begin{array}{l}14.3 \% \text { do nothing, } 8.8 \% \text { try to protect themselves } \\
\text { physically, } 7.1 \% \text { speak directly with the individual }\end{array}$ & 10 \\
\hline \multicolumn{10}{|c|}{ Data collection tool: Other scales } \\
\hline $\begin{array}{l}\text { Arsoy (2011) } \\
\text { Master's thesis }\end{array}$ & Descriptive & $\begin{array}{l}\text { Isparta, } \\
\text { Antalya } \\
\text { and Burdur }\end{array}$ & $\begin{array}{l}\text { Nurses in primary, } \\
\text { secondary and tertiary } \\
\text { public and private health } \\
\text { institutitions }(\mathrm{n}=382)\end{array}$ & N/A & $\begin{array}{l}51.2 \% \text { unjustified criticism, } 46.5 \% \text { \%iving important tasks } \\
\text { to other employees less qualified than } \\
\text { victim, } 42.3 \% \text {. } \\
\text { vegative conversations among colleagues }\end{array}$ & $\begin{array}{l}43.1 \% \text { colleagues, } \\
40.2 \% \text { physicians, } \\
16.7 \% \text { head nurses }\end{array}$ & $\begin{array}{l}\text { 38.1\% feel demoralized in workplace, } \\
37.5 \% \text { have sleeping disorders, } \\
35.1 \% \text { experience enervous breakdown, } \\
16.9 \% \text { experience depression }\end{array}$ & $\begin{array}{l}83.5 \% \text { share experience with friends, } 60.9 \% \\
\text { remain silent and passive, } 56.5 \% \text { consider quitting } \\
\text { profession }\end{array}$ & 9 \\
\hline $\begin{array}{l}\text { CevikAkyil et } \\
\text { al. (2012) } \\
\text { Article }\end{array}$ & Descriptive & $\begin{array}{l}\text { A city in } \\
\text { west } \\
\text { Anatolian } \\
\text { region }\end{array}$ & $\begin{array}{l}\text { Nurses in a university } \\
\text { hospital }(\mathrm{n}=180)\end{array}$ & $\begin{array}{l}\text { Average point of mobbing } \\
\text { perception: 155.51 114.956 } \\
\text { (min: } 36 \text {, max }=180), \\
\text { signifying regular and } \\
\text { frequent experiences }\end{array}$ & $\mathrm{N} / \mathrm{A}$ & $58.9 \%$ supervisors & 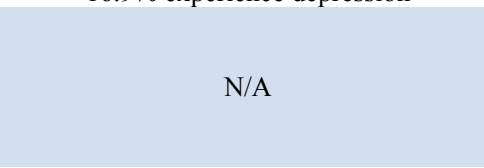 & $31.7 \%$ accept the situation and do not complain & 11 \\
\hline $\begin{array}{l}\text { Dilman (2007) } \\
\text { Master's thesis }\end{array}$ & Descriptive & Istanbul & $\begin{array}{l}\text { Nurses in three private } \\
\text { hospitals }(\mathrm{n}=253)\end{array}$ & $\begin{array}{l}70 \% \text { experience emotional } \\
\text { abuse, distributed as } 91.8 \% \\
\text { low level, } 37.9 \% \text { medium } \\
\text { level and } 42.2 \% \text { high level } \\
\text { abuse }\end{array}$ & $\begin{array}{l}2.8 \% \text { spreading rumors regarding victim, } \\
\% 2.8 \text { trying to make victim quit, } \\
2.8 \% \text { indiriectly controlling victims or thir jobs, } \\
2.8 \% \text { demanding unrealistic deadlines }\end{array}$ & $\begin{array}{l}52.5 \% \text { physicians } \\
37.9 \% \text { patients and their relatives } \\
36.7 \% \text { nurse supervisors }\end{array}$ & 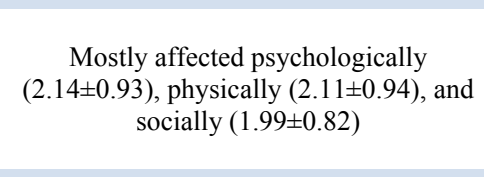 & $\begin{array}{l}45.2 \% \text { share with friends, } \\
42.2 \% \text { inform supervisor, } \\
33.3 \% \text { remain silent and passive, and attempt to } \\
\text { solve the problem by directly speaking with the } \\
\text { individual, } 7.3 \% \text { consider quitting profession }\end{array}$ & 10 \\
\hline $\begin{array}{l}\text { Aksu\&Akyol } \\
(2009) \\
\text { Article }\end{array}$ & Descriptive & Izmir & $\begin{array}{l}\text { Nurses in Intensive Care } \\
\text { Units of public and private } \\
\text { hospitals }(\mathrm{n}=162)\end{array}$ & $\begin{array}{l}71 \% \text { have experienced } \\
\text { mobbing throughout their } \\
\text { career }(\mathrm{n}=115)\end{array}$ & $\begin{array}{l}\text { Effect on psychology: extreme level }(33.2 \pm 7.6) \text {, } \\
\text { average of total score: moderate level }(78.9 \pm 20.3)\end{array}$ & $\mathrm{N} / \mathrm{A}$ & $\begin{array}{l}\text { 93.9\% silently weep without no reason, } \\
88.7 \% \text { feel loss of personal integrity, } \\
85.2 \% \text { negatively affected in private lives }\end{array}$ & $\begin{array}{c}83.5 \% \text { share with friends, } \\
60.9 \% \text { remain silent, } \\
56.5 \% \text { consider quitting profession }\end{array}$ & 9 \\
\hline
\end{tabular}




\begin{tabular}{|c|c|c|c|c|c|c|c|c|c|}
\hline $\begin{array}{l}\text { Fiskinn (2011) } \\
\text { Master's thesis }\end{array}$ & Descriptive & Istanbul & $\begin{array}{l}\text { All healthcare workers in } \\
\text { Maternal and Child Health } \\
\text { and Family Planning } \\
\text { Centers }(\mathrm{n}=62.27 .4 \% \\
\text { nurses }(\mathrm{n}=17)\end{array}$ & $\begin{array}{c}58 \% \text { of all healthare } \\
\text { workers, } 64.7 \% \text { of nurses } \\
(\mathrm{n}=11), 57.1 \% \text { of head nurses } \\
\text { (n=) have experienced } \\
\text { mobbing at least once }\end{array}$ & $\begin{array}{l}\text { According to the scale dimensions: } \\
\text { Communication barriers }(1.75 \pm 0.84) \\
\text { Discrimination }(1.60 \pm 0.88) \\
\text { Humiliation }(1.53 \pm 0.72) \\
\text { Sexual harassment }(1.10 \pm 0.28)\end{array}$ & N/A & $\mathrm{N} / \mathrm{A}$ & $\mathrm{N} / \mathrm{A}$ & 11 \\
\hline $\begin{array}{l}\text { Yilmaz (2013) } \\
\text { Master's thesis }\end{array}$ & Descriptive & $\begin{array}{l}\text { Balıkesir- } \\
\text { Bandırma }\end{array}$ & $\begin{array}{c}\text { All health personnel and } \\
\text { their assistants in public } \\
\text { hospitals }(\mathrm{n}=729), 25.7 \% \\
\text { nurses }(\mathrm{n}=187)\end{array}$ & $\begin{array}{l}\text { General mobbing rate: } 84 \% \text {, } \\
81.8 \% \text { of nurses (n=153) }\end{array}$ & $\mathrm{N} / \mathrm{A}$ & N/A & $\mathrm{N} / \mathrm{A}$ & $\mathrm{N} / \mathrm{A}$ & 11 \\
\hline $\begin{array}{l}\text { YIddz\&YYIldz } \\
\quad \text { (2009) } \\
\text { Article }\end{array}$ & Descriptive & Kars & $\begin{array}{c}\text { Healthcare workers in } \\
\text { public, maternity and } \\
\text { university hospitals as well } \\
\text { as health centers (n=167), } \\
27.5 \% \\
\text { nurses }(\mathrm{n}=46)\end{array}$ & $\begin{array}{l}\begin{array}{l}35.3 \% \text { of healthcare workers } \\
\text { experienced intimidating } \\
\text { behavior }(n=59)\end{array}\end{array}$ & N/A & $\begin{array}{l}67 \% \text { of nurses experience from } \\
\text { physicians }\end{array}$ & N/A & $\mathrm{N} / \mathrm{A}$ & 10 \\
\hline $\begin{array}{l}\text { Güven et al. } \\
\text { (2012) } \\
\text { Article }\end{array}$ & Descriptive & Nevşehir & $\begin{array}{l}\text { Nurses and midwives in } \\
\text { organiizations afflitiated to } \\
\text { the Provincial Health } \\
\text { Directorate } \mathrm{n}=173) \text {, } \\
70.4 \% \text { nurses (n=100) }\end{array}$ & 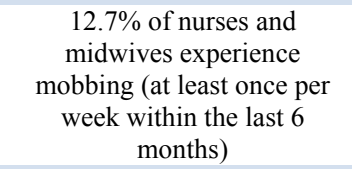 & $\begin{array}{l}\text { Most common subscale: } \\
\text { attacking reputation (37.30 } 14.85) \text {. }\end{array}$ & N/A & N/A & N/A & 11 \\
\hline $\begin{array}{c}\text { Zonp (2012) } \\
\text { Master's thesis }\end{array}$ & $\begin{array}{c}\text { Descriptive } \\
\text { and } \\
\text { Correlational }\end{array}$ & Istanbul & $\begin{array}{l}\text { Nurses in psychiatric } \\
\text { clinics of } 6 \text { hospitals } \\
\text { willing to participate in the } \\
\text { study (n=296) }\end{array}$ & $\begin{array}{l}53 \% \text { of psychiatric nurses } \\
\text { (throughout their career) }\end{array}$ & $\begin{array}{l}25.5 \% \text { monitoring every detail of victim's performance, } \\
6.4 \% \text { questioning professsional decisions made by victim, } \\
4.9 \% \text { assigning responsibilities that are below the victim's } \\
\text { abilities or hurt their self-respect }\end{array}$ & N/A & N/A & N/A & 11 \\
\hline $\begin{array}{l}\text { Yilmazel } \\
\text { (2013) } \\
\text { Article }\end{array}$ & Descriptive & Corum & $\begin{array}{c}\text { Nurses in a public hospital } \\
(\mathrm{n}=129)\end{array}$ & $\begin{array}{l}92.2 \% \text { of nurses(within the } \\
\text { last } 6 \text { months) }\end{array}$ & tes & N/A & N/A & N/A & 10 \\
\hline \multicolumn{10}{|c|}{ Data collection tool: Survey form developed by researchers } \\
\hline $\begin{array}{l}\text { Solakoğlu (2007) } \\
\text { Master's thesis }\end{array}$ & $\begin{array}{l}\text { Descriptive/ } \\
\text { Correlational }\end{array}$ & Eskişehir & $\begin{array}{l}\text { Healthcare workers in a } \\
\text { public hospital }(\mathrm{n}=210), \\
45.3 \% \text { nurses }(\mathrm{n}=95)\end{array}$ & $\begin{array}{l}38.6 \% \text { mobbing victims } \\
\text { (within the last } 6 \text { months) } \\
44.4 \% \text { of victims are nurses } \\
\text { (n=36) }\end{array}$ & $\mathrm{N} / \mathrm{A}$ & 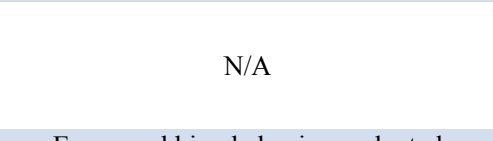 & $\mathrm{N} / \mathrm{A}$ & $\mathrm{N} / \mathrm{A}$ & 10 \\
\hline $\begin{array}{r}\text { Kaya (2010) } \\
\text { Master's thesis }\end{array}$ & Descriptive & Sivas & $\begin{array}{l}\text { Nurses in Cumhuriyet } \\
\text { University Hospital } \\
(\mathrm{n}=126)\end{array}$ & 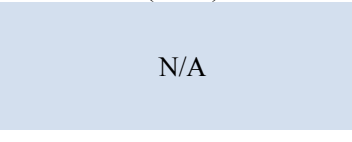 & $\begin{array}{l}\text { 67.5\%insulting victim, } \\
65 \% \text { giving tasks that exceed their capacity, } \\
59.5 \% \text { spreading rumors about victim }\end{array}$ & $\begin{array}{l}\text { Every mobbing behavior evaluated } \\
\text { separately: } \\
\text { generally head nurses, physician and } \\
\text { patients and their relatives }\end{array}$ & N/A & N/A & 10 \\
\hline $\begin{array}{l}\text { Atasoy (2010) } \\
\text { Master's } \\
\text { thesis }\end{array}$ & Descriptive & Sakarya & $\begin{array}{l}\text { Nurses and midwives in } \\
5 \text { public and } 4 \text { private } \\
\text { hospitals (n } \mathrm{n}=364), \\
82.1 \% \text { nurses ( } \mathrm{n}=299)\end{array}$ & $\begin{array}{l}\text { General mobbing experience } \\
\text { rate: } 17.9 \%\end{array}$ & $\begin{array}{l}\text { Most common behavior: controlling victim without being } \\
\text { noticeable, } 17.3 \% \text { in private hopsitials and } 16.3 \% \text { in public } \\
\text { hospitals. } \\
\text { Second most common behavior in public hospitals: } \\
10 \% \text { criticizing victim's uniform and } 10 \% \text { constantly } \\
\text { searching for mistakes in victim's performance }\end{array}$ & $\begin{array}{c}\text { Every mobbing behavior evaluated } \\
\text { separately. } \\
\text { Results for "controlling victim without } \\
\text { being noticeable": } \\
13 \% \text { head nurses, colleagues and } \\
\text { hospital directors, } 10.7 \% \text { physicians, } 8 \% \\
\text { chief physician }\end{array}$ & $\begin{array}{l}\text { Private hospital: } \\
\text { 14.7\% experience head aches } \\
14.1 \% \text { suffer from insomnia } \\
\text { Public hospital: } \\
14.3 \% \text { experience head aches } \\
15.1 \% \text { suffer from insomnia }\end{array}$ & $\begin{array}{l}79.2 \% \text { in private hospital and } 91.1 \% \text { in public } \\
\text { hospital attempt to solve the problem by directly } \\
\text { speaking with the individual. } 5.5 \% \text { in public } \\
\text { hospital (n=15) and } 6.6 \% \text { in private hospital (n=5) } \\
\text { applied for legal charges }\end{array}$ & 10 \\
\hline $\begin{array}{l}\text { Somunoğglu et al. } \\
\quad \text { (2013) } \\
\text { Article }\end{array}$ & Descriptive & Zonguldak & $\begin{array}{l}\text { Nurses in a university } \\
\text { hospital (n=187) }\end{array}$ & N/A & $\begin{array}{l}57.8 \% \text { negative and inulting communication, } \\
22.2 \% \text { verbal violence, } \\
5.9 \% \text { hysical violence, } \\
8 \% \text { \% sexual violence, } \\
17.6 \% \text { preventing means of self-improvement }\end{array}$ & (1) & $\begin{array}{l}15.5 \% \text { experience psychological } \\
\text { problems,2.7\% experience physiological } \\
\text { problems }\end{array}$ & $\begin{array}{l}\text { No reaction, } \\
32.6 \% \text { request to change workplace, } 13.9 \% \\
\text { consider quitting }\end{array}$ & 11 \\
\hline
\end{tabular}

N/A: Not Applicable 